\title{
Urban Governance and the Future of Canadian Federalism
}

\section{Conor Lewis}

\section{Dalhousie University}

The Canadian federation is constantly being reconfigured. Throughout our 147 years of nationhood Canada has evolved from a quasifederal ${ }^{1}$ state to arguably one of the most decentralized federations in the world. However, for all the change that has occurred as we approach our sesquicentennial anniversary urban city centers are still treated as if they are the colonial holdings of their provincial masters. The rigidity in which the constitutional division of powers is interpreted in regards to municipal affairs allows for the continued suppression of urban governance. By not allowing the full participation of urban local government within the federation, Canada has turned a blind eye to the economic realities of the globalized Knowledge Based Economy $(\mathrm{KBE})^{2}$ and the essential role that "Global City Regions (GCRs)" will play as the economic "motors of the information era." ${ }^{3}$ Through the systematic underfunding of our regional economic hubs, ${ }^{4}$ the country is limiting the cultural creativity and fiscal growth of our urban municipalities. In order for Canadian urban centers, and thereby Canada, to thrive municipalities and urban citizens need to apply pressure on the federal and provincial governments to establish a legal framework that if

\footnotetext{
${ }^{1}$ Gregory Inwood, Understanding Canadian Federalism: An Introduction to Theory and Practice (Toronto: Pearson Canada, 2013), 58. Quasi-Federal: coined by K.C. Wheare, it is a model in which provincial governments are seen as subordinate to the federal government.

${ }^{2}$ Thomas J Courchene, "Global Futures for Canada's Global Cities," IRPP Policy Matters 8, no. 2 (2007): 27.

${ }^{3}$ Ibid., 1.

${ }^{4}$ Ibid., 1. There are 9 economic hubs (Vancouver, Edmonton, Calgary, Regina and Saskatoon, Winnipeg, Toronto, Montreal, Halifax).
}

not entrenches, then conventionalizes the processes of multi-level governance between all three levels of the Canadian federation. This analysis leads to the conclusion that the Canadian federation has not adapted sufficiently to the reality of urbanization.

The division of powers between federal and provincial jurisdiction was entrenched in $\mathrm{s.91}$ and s.92 of the British North America Act of 1867. The constitution delineates that the provinces have jurisdiction over municipal institutions and control over generally all matters of a merely local or private nature. ${ }^{5}$ The decision to give the provinces jurisdiction over municipal government was compatible with the demographics of nineteenth century Canada. In 1861 the total urban population of Canada was 527 220, this accounted for only $16 \%$ of the total population. ${ }^{6}$ With the vast majority of the citizenry living in the rural hinterlands urban affairs was not an issue of pressing substance. However, at the time of the last census in 2011 Statistics Canada reported that $81 \%$ of Canadians and $86 \%$ of Ontarians were now a part of the urban population. ${ }^{7}$ Although the overwhelming majority of Canadians now live in cities, municipal governments policymaking

\footnotetext{
${ }^{5}$ Department of Justice Canada, "The Constitution Acts 1867 to 1982," January 1, 2013, Accessed November 1, 2014, http://laws-lois.justice.gc.ca/PDF/CONST E.pdf. The Constitution Acts 1867 to 1982, pg.29. s.92(8) \& s.92(16) of the constitution are referenced here.

6 "Population, Urban and Rural, by Province and Territory (Ontario)." Government of Canada, Statistics Canada. February 4, 2011. Accessed November 1, 2014. http://www.statcan.gc.ca/tables-tableaux/sumsom/l01/cst01/demo62g-eng.htm

${ }^{7}$ Ibid.
} 
powers remain significantly circumscribed by the provincial government ${ }^{8}$.

Municipalities, constitutionally speaking are creatures ${ }^{9}$ of the provinces. Provincial governments are able to create, eliminate, and regulate municipalities. ${ }^{10}$ The jurisdictional rights provided to the provinces allow them to control all aspects of urban development. ${ }^{11}$ The trend towards amalgamation showcases the supremacy of the provinces and the relative weakness of municipalities. The amalgamation of municipalities, argues Caroline Andrew, is "not so much for [the] better capacity [of the municipality] to act but for less expensive city government." ${ }^{12}$ The act of amalgamation makes the territorial boundaries of a municipality larger. Increasing the size of a city, however, diminishes the ability of neighborhoods and individual citizens to influence local decision-making, ${ }^{13}$ by expanding further away from the city center suburban voices are allowed to have an influence on urban decision making.

In January 2001 the five municipalities surrounding Hamilton (Ancaster, Dundas, Flamborough, Glanbrook, and Stoney Creek) were amalgamated to form the City of Hamilton. ${ }^{14}$ The

\footnotetext{
${ }^{8}$ Patrick Smith and Kennedy Stewart, "Local Whole-ofGovernment Policymaking in Vancouver: Beavers, Cats, and the Mushy Middle Thesis," In Canada: The State of the Federation 2004 : Municipal-federal-provincial Relations in Canada. Montréal, Quebec: McGill-Queen's University Press ; 2006, 258.

${ }^{9}$ Courchene, Global Futures of Canada's Global Cities, 1.

${ }^{10}$ Robert Young, "Multilevel Governance and Public Policy in Canadian Municipalities: Reflections on Research Results," CPSA/ACSP, June 6, 2013, Accessed November 1, 2014, 1.

${ }^{11}$ Caroline Andrew, "The Shame of Ignoring the Cities," Journal of Canadian Studies 7, no. 4 (2001): 105.

12 Ibid., 108.

${ }^{13}$ Andrew Sancton, "Beyond the Municipal: Governance for Canadian Cities," February, 2004, Accessed

November 1, 2014, http://policyoptions.irpp.org/issues/canadascities/beyond-the-municipal-governance-for-canadiancities/, 29.

14 "Hamilton at a Glance," City of Hamilton - 2014, Accessed November 1, 2014, http://www.hamilton.ca/CityDepartments/CorporateSe rvices/AccessEquity/HamiltonAtAGlance.htm.
}

former suburbs were given an equal place at Hamilton City Hall, but the issues that the suburban citizen wants addressed are drastically different then the issues that are plaguing the inner city. [See Table 1];

\begin{tabular}{|l|l|l|}
\hline \multicolumn{3}{|l|}{ Hamilton 2005: Average Household Income } \\
\hline Ward & $\begin{array}{l}\text { Average } \\
\text { Household } \\
\text { Income }\end{array}$ & $\begin{array}{l}\text { Total Number } \\
\text { of Private } \\
\text { Household }\end{array}$ \\
\hline Ward 2 & $\$ 41,307$ & 19,430 \\
\hline Ward 3 & $\$ 45,481$ & 16,730 \\
\hline $\begin{array}{l}\text { Ward 12 } \\
\text { (Formally } \\
\text { Ancaster) }\end{array}$ & $\$ 126,715$ & 10,070 \\
\hline $\begin{array}{l}\text { Ward 14 } \\
\text { (Formally } \\
\text { Flamborough) }\end{array}$ & $\$ 96,633$ & 8,375 \\
\hline City of Hamilton & $\$ 70,025$ & 194,455 \\
\hline
\end{tabular}

[Table 1]

http://www.investinhamilton.ca/wpcontent/uploads/2013/10/SSSP-WardProfiles-

Ward2.pdf (Ward 2)

http://www.investinhamilton.ca/wpcontent/uploads/2013/10/SSSP-WardProfilesWard3.pdf (Ward 3) http://www.investinhamilton.ca/wpcontent/uploads/2013/10/SSSP-WardProfiles-

Ward12.pdf (Ward 12)

http://www.investinhamilton.ca/wpcontent/uploads/2013/10/SSSP-WardProfilesWard14.pdf (Ward 14) http://www.hamilton.ca/CityDepartments/Corpor ateServices/AccessEquity/HamiltonAtAGlance.htm

A quick glance at the above table reveals apparent economic disparity between wards. The mean household income in suburban Ward 12 is three times greater than the mean income in inner city Ward 2. The above data begs the question: how can coherent plans for social action be devised when trying to administer a local government that appeases the desires of the very wealthy and at the same time provides a fair standard of living for the urban poor? The simple 
answer is that without increased jurisdictional and fiscal powers municipalities do not have the resources to solve these problems.

Provinces have simultaneously been amalgamating municipalities while downloading programs that deal with the management of social diversity onto the shoulders of urban cities. This increase in jurisdictional powers, however, has come without an increase in financial resources. ${ }^{15}$ The result, Caroline Andrew, finds "has been for local governments to think more of cost-cutting than of increased service. ${ }^{\prime 16}$ If urban cities were given the monetary tools as well as the jurisdictional powers to create social policy, "cities would approach their newfound responsibilities in myriads of creative ways." ${ }^{17}$ There would be a reimagining of the competitive era of federalism and creative asymmetry would create novel programs, the best of which presumably would be replicated in other cities. ${ }^{18}$

A major reason for which the evolution of urban governance has stagnated over the past decade is because of the Harper Government's approach to federalism. The Prime Minister's policy of open federalism advocates for the provinces to "exercise their full jurisdictional responsibilities without federal interference." ${ }^{19}$ Harper's decision to embrace a neo-classical version of federalism is characteristic of the myopathy of senior levels of government in regards to urban issues ${ }^{20}$. By affirming the provinces jurisdiction over municipal institutions, the Prime Minister willfully elected to discount the importance of the fact that over half the population of Canada now resides in 10 Census

\footnotetext{
${ }^{15}$ Andrew, "The Shame of Ignoring the Cities", 102.

${ }^{16}$ Andrew, "The Shame of Ignoring the Cities", 107.

${ }^{17}$ Courchene, "Global Futures for Canada's Global Cities", 26.

18 Ibid.

${ }^{19}$ Inwood, Understanding Canadian Federalism, 164

${ }^{20}$ Loleen. "The Federal Urban Role and FederalMunicipal Relation In Canada." The State of the Federal 2004: Municipal-federal-provincial Relations in Canada, 2006, 36. Senior Level of government refers to federal and provincial governments.
}

Metropolitan Areas (CMA $)^{21}[$ See Table 2]. Now more than ever "what goes on in our cities is more crucial to the economic well being of Canada than what goes on in our mines, farms and fishing boats." 22

[Table 2]

\begin{tabular}{|c|c|}
\hline \multicolumn{2}{|c|}{ Most Populous Census Metropolitan Areas 2011} \\
\hline $\begin{array}{l}\text { Census Metropolitan } \\
\text { Areas }\end{array}$ & $\begin{array}{l}\text { Population } \quad \text { (in } \\
\text { thousands) }\end{array}$ \\
\hline Toronto & $5,769.8$ \\
\hline Montreal & $3,885.7$ \\
\hline Vancouver & $2,373.0$ \\
\hline Ottawa & $1,270.2$ \\
\hline Calgary & $1,264.5$ \\
\hline Edmonton & $1,206.0$ \\
\hline Quebec City & 776.8 \\
\hline Winnipeg & 746.1 \\
\hline Hamilton & 742.5 \\
\hline $\begin{array}{l}\text { Kitchener-Cambridge- } \\
\text { Waterloo }\end{array}$ & 493.0 \\
\hline Total & $18,527.6$ \\
\hline Canada & $34,342.8$ \\
\hline $\begin{array}{l}\text { Percentage of the } \\
\text { Population living Top } \\
\text { Ten most Populous CMA }\end{array}$ & $53.9 \%$ \\
\hline
\end{tabular}

http://www.statcan.gc.ca/tables-tableaux/sumsom/l01/cst01/demo02a-eng.htm (Canada) http://www.statcan.gc.ca/tables-tableaux/sumsom/l01/cst01/demo05a-eng.htm (CMAs)

"In an increasingly borderless world, local communities everywhere are less protected by national governments." 23 "The global forces and the imperatives of economic competition make

\footnotetext{
${ }^{21}$ Statistic Canada Defines a Census Metropolitan Area as: Area consisting of one or more neighbouring municipalities situated around a core. A census metropolitan area must have a total population of at least 100,000 of which 50,000 or more live in the core (http://www12.statcan.gc.ca/censusrecensement/2011/ref/dict/geo009-eng.cfm).

${ }^{22}$ Sancton, "Beyond the Municipal", 30.

${ }^{23}$ Christopher Leo. "Deep Federalism: Respecting Community Difference in National Policy." Canadian Journal of Political Science/Revue Canadienne De Science Politique 39, no. 3 (2006): 482.
} 
municipal evolution inevitable." ${ }^{24}$ Our future relies on the critical role our Global City Regions will play in the near future to increase the potential of the Canadian economy. ${ }^{25}$ They must attract the best talent have access to the best technology and they need to provide a tolerant atmosphere for all forms of creativity to thrive ${ }^{26}$. As of right now urban governments have not been given the tools they need to excel in the world marketplace. Courchene suggests that in order for Global City Regions to achieve meaningful revenue autonomy, cities need access to broader bases of taxation. ${ }^{27}$

Currently the majority of municipalities' revenue comes in the form of property taxes. This single tax is by no means expansive enough to encourage the development of local governance. In order for our Global cities to emerge as world leaders, they need to establish multi-lateral agreements with the federal and provincial governments that would ensure a sharing of the transfer of tax based upon what was actually collected from the municipality in the first place. ${ }^{28}$ It would be through a tax transfer program based on proportional redistribution of tax revenue that the emergence of our global cities would be ensured. Since GCRs are hubs for immigration and resettlement, their growing tax base will ensure their future prosperity and autonomy. ${ }^{29}$ The issue as it is now exists, however, is that all the aforementioned powers do not exist for municipal governments. Restrictions on revenue sources make it impossible for the city to maintain, let alone improve, existing infrastructure and service delivery. ${ }^{30}$ The limited ability to implement change in our urban neighbourhoods because of the lack of municipal autonomy keeps innovative individuals away from participating in

\footnotetext{
${ }^{24}$ Young, "Multilevel Governance and Public Policy in Canadian Municipalities", 14.

${ }^{25}$ Kiel \& Young, A Charter for the People, 88.

${ }^{26}$ Courchene, "Global Futures for Canada's Global Cities", 5.

27 Ibid., 12.

28 Ibid., 17.

${ }^{29}$ Courchene, "Global Futures for Canada's Global Cities", 24-25.

${ }^{30}$ Kiel, “A Charter for the People?,", 88.
}

local government. It is those very people that we need, however, to secure economic success of our future.

In Courchene's paper Global Futures for Canada's Global Cities, he makes detailed reference to the Hancourt Report and its call for a double devolution in powers. If a double devolution were to occur it would consist of the "federal government [shifting] responsibilities and resources onto the provinces and they in turn would move those powers to the local level." ${ }^{31}$ The double devolution, according to the Hancourt Report would "ensure that choices about how to raise and use resources, including tax choices, move to the most appropriate local levels, where accountability to citizens is most direct." ${ }^{32}$ For real change in the federal stance towards municipalities to occur there would need to be intense lobbying effort conducted horizontally by large urban city leaders. ${ }^{33}$ If a larger role for municipalities in federalism was to be won there would be not only a larger role for the cities, but also a further devolution of power to individual neighbourhoods. The chance to bring Canadian federalism down to the local level is an exhilarating thought about the possible evolution of our democracy. By broadening the tax revenue that municipalities can draw upon through tax transfer programs, local participatory budgeting initiatives can become more commonplace and elaborate, bringing more people into local government. When we deprive our global cities of the ability to self determine, it is to the detriment of the city and to local democracy, and on a larger scale, to the detriment of the national economy. Canadian federalism needs to recognize the emerging role of cities as the pistons of the economic engine that will drive the economy into the information age. 34

${ }^{31}$ Courchene, "Global Futures for Canada's Global Cities", 22.

32 Ibid.

${ }^{33}$ Young, "Multilevel Governance and Public Policy in Canadian Municipalities", 2.

${ }^{34}$ Courchene, "Global Futures for Canada's Global Cities:, 5. 
In order for cities to emerge in the globalized world as economic and cultural powerhouses, they need to be given the authority to communicate with the federal and provincial governments with some level of jurisdictional authority. The way that more power will be won by municipal governments is through intergovernmental agreements enshrined into law. Courchene reminds us that our "Global City Regions have the critical civil-servant mass for effective policy design." ${ }^{35}$ By communicating within the multi-level governance framework municipalities can lobby their way into conventionalized autonomy. Issues occur about establishing lasting dialogues regarding municipal autonomy, "namely the sheer turnover of political leadership." ${ }^{36}$ Compounding the problem of political turnover are the complex relationships that already exist between federal and provincial governments and make embracing a third member a challenging task. The provinces' complete jurisdiction over municipalities means that even if a federal government was elected on the platform of municipal autonomy provinces could constitutionally challenge any purposed law that would restrict their sweeping jurisdiction over urban affairs. The greatest chance for the urbanization of Canadian federalism comes in the strengthening of intrastate institutions.

As it stands, "Ottawa has no central institutions for liaison with the municipal sector as a whole." 37 Loleen Berdahl advocates for institutionalizing urban affairs at the federal level. Some form of "federal consultation mechanism such as the establishment of a federal standing committee on urban affairs", argues Berdahl, would "institutionalize federal consultation with provincial and municipal government." ${ }^{38}$ While this reform does not seem likely under the Harper

\footnotetext{
${ }^{35}$ Ibid., 35.

${ }^{36}$ Young, "Multilevel Governance and Public Policy in Canadian Municipalities", 5.

${ }^{37}$ Young, "Multilevel Governance and Public Policy in Canadian Municipalities", 5.

${ }^{38}$ Berdahl, "The Federal Urban Role and FederalMunicipal Relations", 37.
}

administration the citizenry in the upcoming federal election will have the ability to choose a new vision of how municipalities fit into the federalist scheme. Viewing the recent electoral results in the Ontario provincial election we can see how the urban centers are voting with the party that is advocating a more city centered agenda. [See Image 1]

[Image 1] 2014 Ontario Election Results
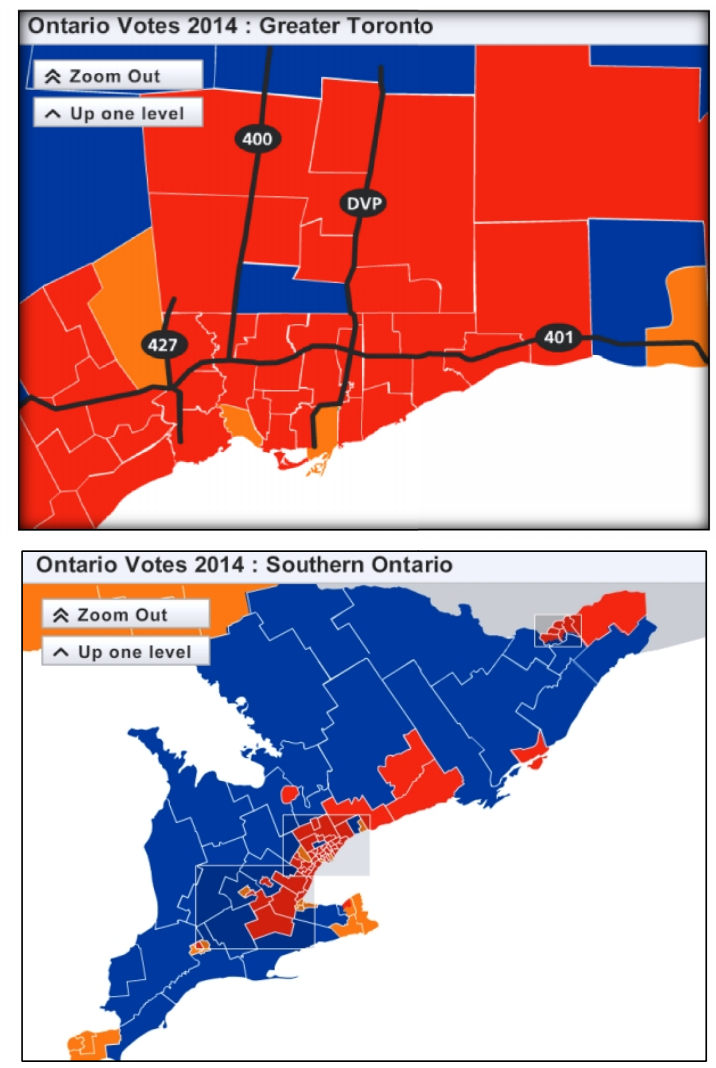

http://www.cbc.ca/elections/ontariovotes2014/ (CBC)

There are 107 total seats in the Ontario Provincial Legislature. In order to obtain a majority, a single party must win 54 ridings. The current Liberal government won 19 out of a possible 22 within the City of Toronto ${ }^{39}$. What is even more interesting, however, is the fact that the liberals were able to decimate the

\footnotetext{
${ }^{39}$ Alcoba, Natalie. "Ontario Election Results: Liberals Ride to Majority on Strength of Toronto's 416." National Post Ontario Election Results Liberals Ride to Majority on Strength of Torontos416 Comments. June 12, 2014. Accessed November 1, 2014. http://news.nationalpost.com/2014/06/12/ontarioelection-results-liberals-ride-to-majority-on-strengthof-torontos-416/
} 
Conservatives in the suburbs of the Greater Toronto Area. When we broaden our view, we see that the Grits took 37 of the 47 seats that were up for grabs in the Greater Toronto Area. In The Shame of Ignoring the Cities, Caroline Andrews states that "without public intervention, there will be a growing tendency at the provincial level for cleavages to widen between the metropolitan centers and the rest of the provincial population." ${ }^{40}$ The most recent Ontario election does a fantastic job of illustrating the growing cleavage in political ideology that exists between the metropolitan centers and the surrounding rural areas, since what urban cities need and desire is fundamentally different than the needs and wants of rural ridings. If citizens of cities want more say in and more power for their local government they need to say so with their feet. Through provincial elections and the process of intrastate federalism, cities can vote for provincial parties that are the most likely to be open to sharing certain jurisdictional responsibilities. As Courchene reminds us, real breakthrough will probably have to come from the provinces ${ }^{41}$. Dialogue is essential but it will only be through legislation that cities will better be able to set their local agenda to deal with their local needs.

Canada was established on the principles of tradition and loyalty. These principles, although essential for maintaining peace, order, and good governance do not lend themselves well to reform. Although Canada is not prone to implementing reforms dealing with the jurisdictional separation of powers, the current circumstances call for a devolution of powers accompanied by a transference of the financial tools to the urban Global Cities to ensure limited self-autonomous government. The strict legalistic reading of the constitution has kept the principle motors of our economy chained to their provincial master for too long. The economic success of Canada, as we move into a more globally

\footnotetext{
${ }^{40}$ Andrew, "The Shame of Ignoring the Cities", 102.

${ }^{41}$ Courchene, "Global Futures for Canada's Global Cities", 27.
}

competitive era relies on the emergence of institutionalized multi-level governance. It is the job of the urban citizen and rural citizen alike to become politically active in their local communities and to demand change through their vote. The division of powers found in the Canadian constitution is a relic of a colonial world. It is and will continue to be irresponsible for the federal and provincial governments to shackle the country to this agreement based on blind faith alone. The time is now to secure greater municipal autonomy. 


\section{Bibliography}

Alcoba, Natalie. "Ontario Election Results: Liberals Ride to Majority on Strength of Toronto's 416." National Post Ontario Election Results Liberals Ride to Majority on Strength of Torontos416 Comments. June 12, 2014. Accessed November 1, 2014. http://news.nationalpost.com/2014/06/12/ontario-electionresults-liberals-ride-to-majority-on-strength-of-torontos-416/

Andrew, Caroline. "The Shame of Ignoring the Cities." Journal of Canadian Studies 7, no. 4 (2001): 110-11.

Berdahl, Loleen. "The Federal Urban Role and Federal-Municipal Relation In Canada." The State of the Federal 2004: Municipal-federal-provincial Relations in Canada, 2006.

Statistics Canada "Census Metropolitan Area (CMA) and Census Agglomeration (CA)." - Census Dictionary. December 12, 2012. Accessed November 1, 2014.

City of Hamilton. "City of Hamilton Ward Profiles: Ward 2." Accessed November 1, 2014. http://www.investinhamilton.ca/wp-content/uploads/2013/10/SSSP-WardProfiles-Ward2.pdf

City of Hamilton. "City of Hamilton Ward Profiles: Ward 3." Accessed November 1, 2014. http://www.investinhamilton.ca/wp-content/uploads/2013/10/SSSP-WardProfiles-Ward3.pdf

City of Hamilton. "City of Hamilton Ward Profiles: Ward 12." Accessed November 1, 2014. http://www.investinhamilton.ca/wp-content/uploads/2013/10/SSSP-WardProfiles-Ward12.pdf

City of Hamilton. "City of Hamilton Ward Profiles: Ward 14." Accessed November 1, 2014. http://www.investinhamilton.ca/wp-content/uploads/2013/10/SSSP-WardProfiles-Ward14.pdf

Courchene, Thomas J. "Global Futures for Canada's Global Cities." IRPP Policy Matters 8, no. 2 (2007): 27.

"Hamilton at a Glance." City of Hamilton -. 2014. Accessed November 1, 2014. http://www.hamilton.ca/CityDepartments/CorporateServices/AccessEquity/HamiltonAtAGlance.htm.

Inwood, Gregory. Understanding Canadian Federalism: An Introduction to Theory and Practice. Toronto: Pearson Canada, 2013.

Kiel, Roger, and Douglas Young. "A Charter for the People? A Research Note on the Debate about Municipal Autonomy in Toronto." Urban Affairs Review 39, no. 87 (2003).

Leo, Christopher. "Deep Federalism: Respecting Community Difference in National Policy." Canadian Journal of Political Science/Revue Canadienne De Science Politique 39, no. 3 (2006): 481-506.

News, CBC. "Home - Ontario Votes 2014 - CBC News." CBCnews. April 10, 2013. Accessed November 1, 2914. http://www.cbc.ca/elections/ontariovotes2014/.

"Population of Census Metropolitan Areas." Government of Canada, Statistics Canada. May 30, 2014. Accessed November 1, 2014. http://www.statcan.gc.ca/tables-tableaux/sumsom/l01/cst01/demo05a-eng.htm.

"Population by Year, by Province and Territory (Number)." Government of Canada, Statistics Canada. September 6, 2014. Accessed November 1, 2014. http://www.statcan.gc.ca/tables-tableaux/sumsom/l01/cst01/demo02a-eng.htm. 
"Population, Urban and Rural, by Province and Territory (Ontario)." Government of Canada, Statistics Canada. February 4, 2011. Accessed November 1, 2014. http://www.statcan.gc.ca/tables-tableaux/sumsom/l01/cst01/demo62g-eng.htm

Sancton, Andrew. "Beyond the Municipal: Governance for Canadian Cities." February, 2004. Accessed November 1, 2014. http://policyoptions.irpp.org/issues/canadas-cities/beyond-the-municipalgovernance-for-canadian-cities/.

Smith, Patrick, and Kennedy Stewart. "Local Whole-of-Government Policymaking in Vancouver: Beavers, Cats, and the Mushy Middle Thesis." In Canada: The State of the Federation 2004 : Municipal-federalprovincial Relations in Canada. Montréal, Quebec: McGill-Queen's University Press ;, 2006.

Department of Justice Canada. "The Constitution Acts 1867 to 1982." January 1, 2013. Accessed November 1, 2014. http://laws-lois.justice.gc.ca/PDF/CONST E.pdf.

Young, Robert. "Multilevel Governance and Public Policy in Canadian Municipalities: Reflections on Research Results." CPSA/ACSP. June 6, 2013. Accessed November 1, 2014. 